\title{
WATER LEVEL VARIATIONS FOR EGG HATCHABILITY AND LARVAL SURVIVAL OF KELABAU FISH (Osteochilus melanopleura Blkr)
}

\author{
Rukmini \\ Department of Aquaculture, Faculty of Fisheries and Marine Sciences \\ Lambung Mangkurat University, Banjarbaru, Indonesia \\ Email : rukmini_bp@yahoo.com
}

\begin{abstract}
The purposes of this study were to observe and analyze the water level variations of the culture media that were optimal for egg hatchability and larval survival of kelabau fish kept in aquarium. This study was conducted in the Freshwater Aquaculture Development Centre (FADC) Banjar Regency in August 2015. The method used in this study was experimental, using a completely randomized design with 3 treatments $(A=$ water level of $15 \mathrm{~cm} /$ aquarium $),(B=$ water level of $25 \mathrm{~cm}$ /aquarium), ( $\mathrm{C}=$ water level of $35 \mathrm{~cm}$ /aquarium) and 3 replications. The parameters measured in this study were the egg hatchability, survival rate, relative growth rate, and water quality (temperature, $\mathrm{pH}, \mathrm{DO}$, Ammonia). Data were analyzed by Anova and the differences between treatments were tested with Duncan test. The results showed that the water level very significantly affected the egg hatchability with the highest value in $B$ (38.29\%) followed by $C(31.83 \%)$ and $A$ $(14.04 \%)$. The highest survival rate was in C $(79.73 \%)$ followed by B $(65.10 \%)$ and A $(21.83 \%)$. The relative growth rate had not significant effect with the average results between all treatments (104.92 - 117.27\%). The water quality of the culture media was still good to support the growth and survival of fish.
\end{abstract}

Keywords: egg hatchability, kelabau fish, survival rate, water level

\section{INTRODUCTION}

Kelabau fish (Osteochilus
melanopleura) is the local fish with
economic value, living in the waters that
are common in Kalimantan and Sumatra.
The current population of kelabau fish has
been declining and the fish is rarely found.

The cultivation of kelabau fish is unfortunately still rare that causes the limited fish production depending on the seasons of fish capture (Mardani, 2014).

Kelabau fish is commonly found in the depths of the middle to the bottom of small and large streams and in flooded areas. Kelabau is herbivore fish that eats the leaves of aquatic macrophytes, flooded terrestrial vegetation, algae, and phytoplankton. The habitats of kelabau fish are streams, creeks and ex-river channel lakes, among the lush aquatic plants that grow in these waters (Weeber, 1916).

Some breeders begin to cultivate the seeds of kelabau fish they obtained from nature. To support the sustainability of this aquaculture, the continuous supply of fish seeds is urgently needed. The availability of kelabau fish seeds in nature is endangered but the domestication and hatchery of this local fish have not really been mastered by the hatchery fish centers owned by both public and private (Asyari, 2007).

One of the main problems in the supply of kelabau fish seeds is that the hatchery and survival rates of cultured larvae are still low. The study about how to increase these rates and to provide the seeds is required. The conservation effort can be started by domesticating fish originated from nature using hatchery technologies. Finally, with better technologies of aquaculture, the obstacles in producing fish seeds can be overcome so as to support the conservation of fish resources.

\section{MATERIALS AND METHODS}

This study was conducted at the Freshwater Aquaculture Development Center (FADC) Banjar Regency in August 2015. The fish were obtained from the 
parent kelabau fish in Kapuas River.

The experimental model using a completely randomized design (CRD) was used in the study, with three treatments and three replications. The treatments were treatment A (water level of 15 $\mathrm{cm} /$ aquarium), treatment $B$ (water level of $25 \mathrm{~cm}$ /aquarium), and treatment $C$ (water level $35 \mathrm{~cm}$ /aquarium).

The parameters observed were the egg hatchability, survival rate, relative growth rate, and water quality (temperature, $\mathrm{pH}, \mathrm{DO}$, and ammonia).

The procedures were started with artificial spawning with a ratio of 2 males: 1 females injected with ovaprim hormone with a dose of $0.5 \mathrm{ml} / \mathrm{kg}$ females and 0.3 $\mathrm{ml} / \mathrm{kg}$ males. The eggs that had been fertilized were transferred to the aquarium measuring $60 \times 30 \times 40 \mathrm{~cm}$ with a density of 3000 eggs/aquarium, and the egg hatchability, survival rate and relative growth rate were observed. The water quality parameters were measured at the beginning and end of the study.

\section{RESULTS AND DISCUSSION}

The egg hatchability of kelabau fish treated with the water level variations experienced egg hatchability fluctuation. The average egg hatchability of kelabau fish ranged from $14.04-38.29 \%$ (Figure 1).

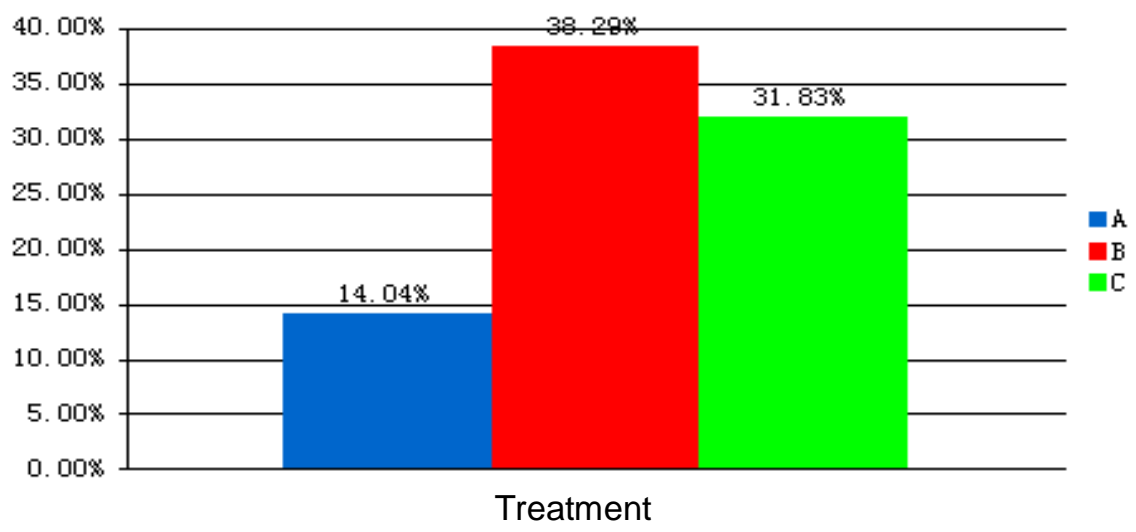

Figure 1 Graph of egg hatchability of kelabau fish

The results of statistical test showed that $F_{\text {count }}(45.84)>F_{\text {table }}, 5 \%(5.14)$ and $1 \%$ (10.92), refusing $\mathrm{H}_{0}$ and accepting $\mathrm{H}_{1}$, which meant the water level variations significantly affected the egg hatchability of kelabau fish. The results of the Duncan test indicated that treatment $B$ was significantly different from treatment $C$, treatment $B$ was significantly different from treatment $A$, and treatment $C$ was significantly different from treatment $A$. Although the results showed differences among treatments, the egg hatchability was still considered low, which was most likely caused by the same density in each aquarium, 3000 eggs, resulting in too crowded number of eggs, that made it difficult for the eggs to move and lack of oxygen that eventually damaged the embryos in the eggs. This is supported by the statement by Sutisna and
Sutarmanto (1995) that hatching occurs when the chorion is destructed by the enzymes made by ectoderm glands and by the movements of embryos due to the increased temperatures, light intensities and dissolved oxygen reduction.

The cause of the low level of hatching is also suspected to be related to the spawning time of kelabau fish. The study was carried out in dry season (August), when the spawning season was over because the spawning of kelabau fish in the wild occurs at the beginning of the rainy season (September to March). It caused poor quality sperm and according to Rukmini (2000), the poor quality sperm can result in the failure of spermatozoa to merge into the egg cell nucleus, hence the eggs do not divide at blastosis stage after fertilization, and the embryos die before 
hatching.

The average survival rate of kelabau larvae ranged from $21.83-79.73 \%$. It can be seen in Figure 2

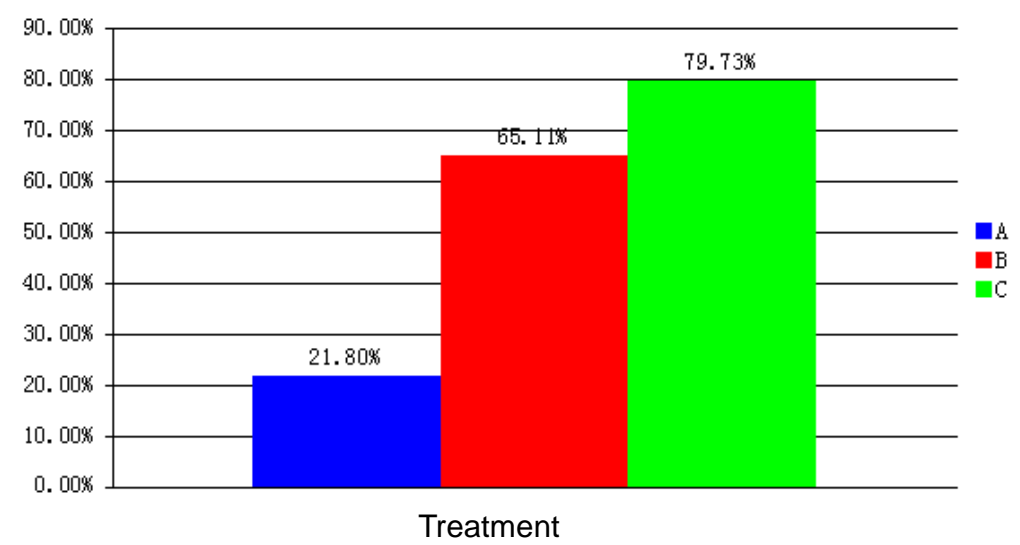

Figure 2 Graph of larval survival of kelabau fish

The results of data statistical test showed that $F_{\text {count }}(29.63)>F_{\text {table }}, 5 \%$ (5.14) and $1 \%$ (10.92), which meant refusing $\mathrm{H}_{0}$ and accepting $\mathrm{H}_{\mathrm{I}}$. It indicated that different variations of water level had a significant effect on the survival of kelabau fish larvae. The results of the Duncan test showed that the treatment $C$ was significantly different from treatment $B$, treatment $C$ was significantly different from treatment $A$, and treatment $B$ was significantly different from treatment $A$. The percentage of larval survival tended to increase with the water level of culture media because the higher water level of the media resulted in the lower competition among fish to obtain space and food. According to Effendi (2004), the fish survival during post larvae is strongly influenced by the availability of food because fish larvae will die in a short time if it does not manage to get food; larvae will experience nutritional deficiencies leading to running out of energy.

The average percentage of the relative growth rate (\%) of kelabau fish larvae ranged from 104.92 to $117.27 \%$.

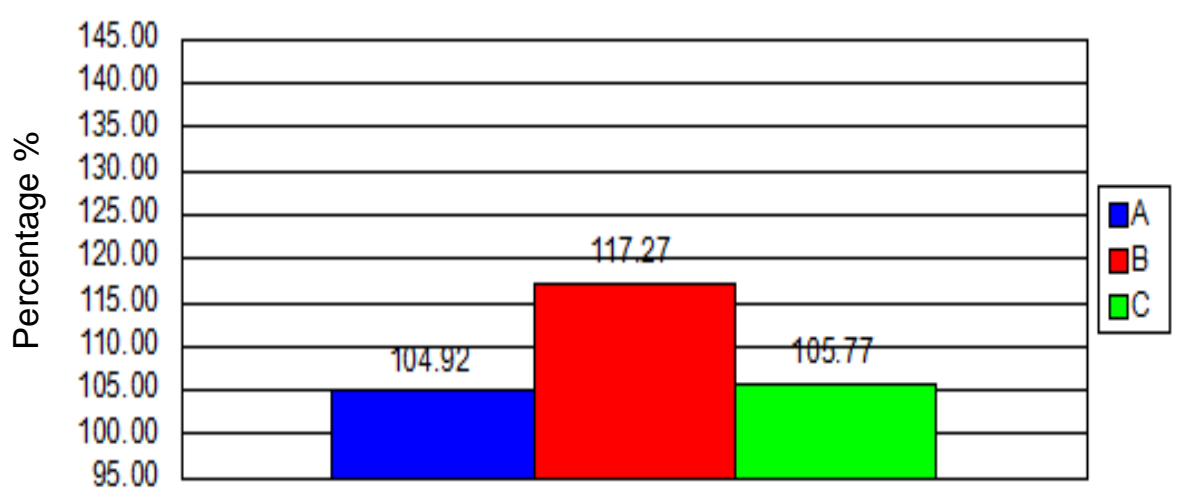

Treatment

Figure 3 Graph of relative growth rate

The results of data statistical test showed that of $F_{\text {count }}(0.38)<F_{\text {table }}, 5 \%$
(5.14) and $1 \%$ (10.92), which meant accepting $\mathrm{H}_{0}$ and refusing $\mathrm{H}_{\mathrm{l}}$. It indicated 
that the different variations of water level did not significantly affect the relative growth rate of kelabau fish larvae.

That there was no significant difference in the values of relative growth rate among all treatments was due to the sizes of larvae when put into ponds (8.52 to $8.57 \mathrm{~mm}$ ) and the growth of length (8.96 to $10.26 \mathrm{~mm}$ ) were relatively the same because of the short culture at the time of egg hatching until spawning.

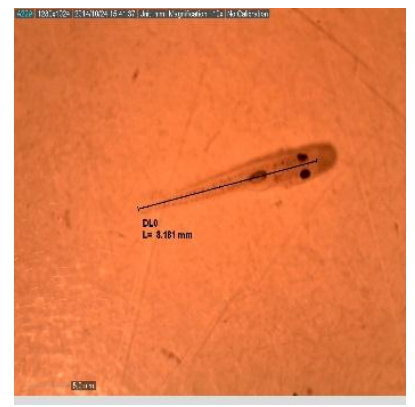

Size of early larvae

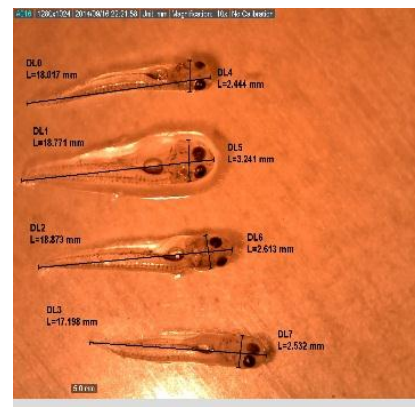

Size of final larvae

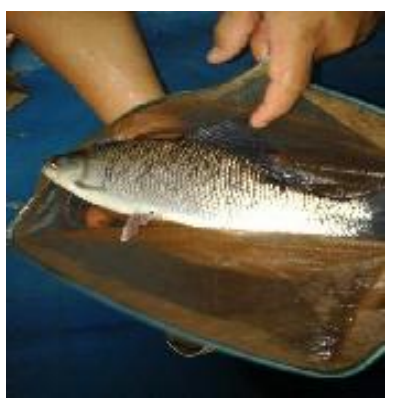

Kelabau fish parent

Figure 4 Measurements of larvae length

The results of water quality measurements demonstrated the range and average values of acidity $(\mathrm{pH})$,

Table 1 Water quality measurements temperature $\left({ }^{\circ} \mathrm{C}\right)$, dissolved oxygen (DO) and ammonia $\left(\mathrm{NH}_{3}\right)$.

\begin{tabular}{ccccc}
\hline \multirow{2}{*}{ Sampling } & \multicolumn{4}{c}{ Average Water Quality Parameters } \\
\cline { 2 - 5 } & $\mathrm{pH}$ & Temperature $\left({ }^{\circ} \mathrm{C}\right)$ & $\mathrm{DO}(\mathrm{mg} / \mathrm{l})$ & Amonia $(\mathrm{mg} / \mathrm{l})$ \\
\hline First & 8.21 & 27.2 & 6.72 & 0.16 \\
Final & 7.86 & 28 & 6.92 & 0.32 \\
Range & $7.42-8.25$ & $26.5-29.7$ & $6.49-7.55$ & $0.11-0.64$ \\
\hline Reference & Mardani (2014) & Mardani (2014) & $\begin{array}{l}\text { Wijayanti et al., } \\
\text { (2011) }\end{array}$ & Cholik (1996) \\
\hline
\end{tabular}

The average values of water quality (temperature, $\mathrm{pH}, \mathrm{DO}, \mathrm{NH} 3$ ) of the culture media for kelabau fish were still within tolerable limits for the fish to support their growth and survival.

\section{CONCLUSIONS}

Water level variations had very significant effects on the egg hatchability and larval survival rate. The lowest egg hatchability was in treatment $A(14.03 \%)$ followed by treatment $C(31.83 \%)$ and the highest was in treatment $B(38.30 \%)$. The lowest survival rate was in treatment $A$ (21.83\%) followed by treatment B $(65.10 \%)$ and the highest was in treatment $C$ $(79.73 \%)$. The results of the average relative growth rate showed that treatment
B was the highest (117.27\%) followed by treatment C (105.77\%), and the lowest was demonstrated by treatment A (104.92\%), but there was no significant difference among the treatments. The measurements of water quality parameters included the level of acidity (7.66 to 8.34), temperature (ranging from $27-29.7^{\circ} \mathrm{C}$ ), dissolved oxygen (6.31 to $7.48 \mathrm{mg} / \mathrm{l})$, and ammonia $(0.11$ to $0.64 \mathrm{mg} / \mathrm{l})$. In general, the overall water quality parameters were still within tolerable limits for kelabau fish to support their growth and survival.

\section{REFERENCES}

Asyari, I. (2007). Effects of Different Spreading Density on Growth of Tilapia Fish (Oreochromis sp.) 
Cultured in a Plastic Basin. Journal of Tropical Fisheries 1 (2) (2006): 119-125. The Department of Fisheries, Faculty of Agriculture, Universitas Kristen Palangkaraya.

Cholik, F., and A. Rahmat, (1986). Water Quality Management in Fish Culture Ponds. pp 51. Directorate General of Fisheries Research Centre. Jakarta.

Effendi., M. I. (2004). Introduction to Aquaculture. Publisher Penebar Swadaya. Jakarta.

Mardani (2014). Effects of Different Food Sources on Growth of Paddy Kelabau Fish (Osteochilus melanopleurus) Cultured in Hapa ponds. Journal of Tropical Animal Sciences 3 (1) (June 2014). Universitas Kristen Palangkaraya.

Rukmini (2000). Effects of Doses and Frequency of ovaprim Inoculation on Spawning of Cork fish (Channa striata Blkr) in a Semi Artificial Way. pp 69. Master Program at Hasanudin University. Makassar..

Rukmini (2012). Technology of Aquatic Biota Culture. pp 235. Publisher Lubuk Agung Bandung, Member of IKAPI. Textbook Grant from Dikti 2011.

Sutisna, D. H. and Sutarmanto, R. (1995). Freshwater Fish Hatchery. Publisher Kanisius. Yogyakarta.

Weber, M. and L.F. de Beaufort (1916). The Fishes of the Indo-Australian Archipelago III: 127-8. E.J. Brill. Leiden.

Wijayanti, G.E., (2011). Technical Guidelines for Hatchery of Nilem Fish (Osteochilus hasselti C.Y) in an intensive manner. Scientific paper. The Faculty of Biology UNSOED, Purwokerto. 